\title{
Studies on Improving Potato Growth, Yield and Quality
}

\author{
El-Anany A. M. A. ${ }^{1}$; Yasser M. M. Osman ${ }^{1}$ and M. M. M. Abd El-Aal ${ }^{2}$ \\ ${ }^{1}$ Potato and Vegetatively Propagated Vegetables Dept., Hort. Res., Inst., A.R.C., Giza, 12619, Egypt \\ ${ }^{2}$ Agricultural Botany Dept., Fac. of Agric., Benha Univ., Moshtohor, Toukh, Qaluobia, 13736, Egypt
}

Corresponding author: rtamsa1999@gmail.com

\begin{abstract}
Two field experiments were carried out to study the effect of some stimulant substances, i.e., benzyladenine at 25,50 ppm and blue green algae "Spirulina platensis" extract at 0.3, $0.6 \%$ as well as yeast extract at 5, 10\% as individual treatments on growth and yield traits in addition to anatomical and chemical constituents of Solanum tuberosum $\mathrm{L}$. The results showed a significant improving in the most of vegetative growth and yield characteristic with applied treatments compared with the control. Consequently, treating potato plants with spirulina algae extract at 0.6 or $0.3 \%$ or yeast extract at $10 \%$, respectively three times lead to obtain vigorous vegetative growth of Solanum tuberosum L. plant with increasing in both of tuber yield and its quality characteristics.
\end{abstract}

Key words: potato, benzyladenine, algae extract, yeast extract, growth, anatomy, phytohormones, yield and tuber quality.

\section{Introduction}

Potato is one of the important vegetable crops in Egypt (Ahmed, 1994). It is consider fourth largest in the world, after rice, wheat and Maize (Ewing, 1997). It is from the richest starchy vegetable crops in terms of energy and nutritional value, it contains a high carbohydrates level and large amounts of vitamins B and C, minerals, fiber, fats and protein (Bach $\boldsymbol{e t}$ al., 2012). Potato is used in several food industries as starch production and alcohol, chips making as well as fried and half-fried potato (Abdel-Aal et al., 1977). Furthermore, potato is contributing in the economy pushing forward through exports as well as it is generating large foreign exchange revenue in addition to the local market needs (Pervez et al., 2000). Researchers are now turning to use modern technologies for increasing production quantity and quality in order to fill the nutritional gap resulting from the population steady increasing viz., utilization of biological fertilizers, natural extracts and growth regulators. Growth regulators are considered one of the most important factors which should be taken in consideration for increasing potato production and tuber quality. Growth regulators are used for increasing production or activate branching which increase vegetative growth which leads to increasing yield. In this respect, benzyl-adenine is plant growth regulators (cytokinins). It is an important plant hormone regulating various processes of plant growth and development including cell division and differentiation, enhancement of leaf expansion and nutrient mobilization as well as increases yield and improves crop quality (Davies, 1995). However, benzyladenine affect plant growth and development and, also implicated in the synthesis of secondary metabolites, vascular development, influences chlorophyll biosynthesis and chloroplast differentiation (Duszka et al., 2009). When exogenously applied, it increases plant height (Letham, 1969), leaf area (Abdullah et al., 1986) and branching (Hrotko et al., 1996). Moreover, the stem end contains an apical bud which causes apical dominance when the stem apex prevents the growth of lateral shoots so that the plant can grow vertically. Once the apical dominance released, elongation and lateral growth is promoted and the lateral buds grow into new branches. The role of cytokinins in lateral growth could be defined into stages, e.g., 1) cytokinin promote lateral bud growth via cell division; 2) auxin is promoted resulting in apical dominance ("imposition of inhibition"); 3) cytokinin released resulting in outward growth of the lateral bud; and then 4) auxin is decreased and gibberellic acid is promoted which results in cell division, enabling the bud or branch to continue outward growth (Cline, 1994). Shoot branching from axillary buds is regulated by a network of inhibitory and promotive forces, which includes hormones (Domagalska and Leyser, 2011). Developmental stages of bud outgrowth are likely associated with checkpoints for feedback regulation and hence enable the homeostasis of shoot number. These stages may also account for the observation that buds at different locations show different responses to signals such as auxin and cytokinin (Dun et al 2006). Whereas, Cline (1994) stated that auxin appears to inhibit axillary bud outgrowth whereas cytokinins will often promote it while, the manipulation of endogenous hormone levels has demonstrated powerful effects of auxin and cytokinin on axillary bud outgrowth.

As for yeast treatment, it is suggested to have a beneficial role during growth and yield due to cytokinins content (Barnett et al., 1990), cell division stimulation, enlargement and synthesis of protein, nucleic acids and chlorophyll (Fathy and Farid, 1996), in addition to its contents of protective components, i.e., sugars, proteins, amino acids and 
several vitamins (Shady, 1978). Improving growth and yield and overall quality of horticultural plants by yeast application was reported by Gomaa et al., (2005), Hussain and Khalaf (2007), Ahmed et al., (2011) and El-Desouky et al., (2011) and Taha and Helal (2019). Concerning to algae extract the beneficial effects of algae extract is a result of many components that may work synergistically at different concentrations (Fornes et al., 2002). Also, algae have contains high levels of organics, micro elements, vitamins, amino acids in addition to growth regulators such as auxins, cytokinin and gibberellins (Blunden, 1991; Crouch and Van Staden, 1994 and Khan et al., 2009). In this respect, El-Sheekh and El- Saied, (1999) stated that the crude extracts of algae increase protein content in foliage, total soluble sugars and chlorophyll in faba bean leaves. Foliar spray with algae extract has been shown to enhance plant growth, yield and its quality on watermelon (Featonby and Van Staden, 1983; Sivasankari et al., 2006 and Abdel Mawgoud et al., 2010), celeriac plant (Shehata et al., 2011), ananas melon (Abd El-Aal,
2012) and garlic (Osman, 2015). Hence, the aim of our research is to study the effect of cytokinin in reduces apical dominance and improving vegetative growth characteristics, tubers yield and quality of potato using some environmentally friendly natural extracts.

\section{Material and Methods}

A field experiment was carried out during two successive summer seasons of 2017 and 2018 at Kaha Vegetable Research Farm, Qalyubia Governorate. The soil was clay loam in texture with $\mathrm{pH} 7.49$, EC 1.94 $\mathrm{dS} . \mathrm{m}^{-1}$. Experiment soil physical and chemical analyses (Table 1) were determined according to procedures described by Jackson (1973). Good quality potato (Solanum tuberosum L.) cv. Picasso seed tubers were used in both seasons. Tubers were planted at a distance of $30 \mathrm{~cm}$ apart on January 27 and 26 of 2017 and 2018, respectively. All agricultural practices were performed as recommended by Ministry of Agriculture and Land Reclamation.

Table 1. Physical and chemical properties of the experimental soil.

\begin{tabular}{|r|c|c|c|c|c|}
\hline \multicolumn{7}{|l|}{ Chemical properties } \\
\hline & 2017 & 2018 & & 2017 & 2018 \\
\hline Sand \% & 18.95 & 19.17 & Available N mg l & 85.56 & 76.77 \\
\hline Silt \% & 17.25 & 19.09 & Available P mg l & 6.13 & 4.63 \\
\hline Clay \% & 59.78 & 60.00 & Available K mg l & 189.44 & 200.76 \\
\hline
\end{tabular}

\section{The experiment treatments:}

The experiment included seven treatments with three replicates arranged in a randomized complete blocks design, i.e., 25, $50 \mathrm{ppm}$ of benzyladenine (BA); $0.3,0.6 \%$ of algae extract; $5,10 \%$ of yeast extract and control (distilled water), were sprayed three times using atomizer at 30, 45 and 60 days after planting along with triton $\mathrm{B}$ as a wetting agent at $0.1 \%$ to improve adherence of the spray to the plant foliage for increasing absorption by the plants. Each experimental plot $\left(12 \mathrm{~m}^{2}\right)$ contained four ridges; each was 4 meter in length and 0.75 meter in width. Each plot received 1.5 - 2 liter solution of each concentration according to the age of the plant. The untreated plants (control) were sprayed with tap water and spreading agent. One line was left between each two experimental plots without spraying as a guard row to avoid the overlapping of spraying solution. Spirulina platensis algae powder was obtained from Algal Biotechnology Unit, National Research Center, Dokki ,Giza , Egypt, , while both benzyladenine $\left(\mathrm{C}_{12} \mathrm{H}_{11} \mathrm{~N}_{5}\right)$ and yeast (Saccharomyces cerevisiae) were obtained from El-Gomhoria Company for Chemicals, Egypt.

\section{Extracts Preparing:}

Yeast extract was prepared from active dry yeast according to the method of Morsi et al. (2008) by dissolving amount of dry yeast in water followed by adding sugar at a ratio of 1:1 and kept 24 hours in a warm place for reproduction. Algal aqueous extract was prepared by macerating $100 \mathrm{~g}$ of S. platensis powder with $1000 \mathrm{ml}$ of distilled water. This mixture was then placed on intermittent agitation for 24 hours, and Supernatant was separated and treated as an algal filtrate $(100 \%)$ and then foliarly applied to the plants as an aqueous solution at both different concentrations $(0.3$ and $0.6 \%, v / v)$. Chemical composition of both Spirulina platensis and yeast extracts are shown in Table (2).

\section{Sampling and Collecting Data}

Five plants from each replicate were randomly taken at 75 days after planting (DAP) and then separated into their organs and the following characteristics were recorded: Plant length $(\mathrm{cm})$, main stems number, lateral stems number, leaves number, fresh and dry leaves weight $(\mathrm{g})$, fresh and dry stems weight $(\mathrm{g})$ and leaf area $\left(\mathrm{cm}^{2}\right)$. Determination of photosynthetic pigments in Solanum tuberosum L. leaves i.e., chlorophyll A, B, A+B and carotenoids mg $\mathrm{g}^{-1}$ FWt. were calorimetrically determined according to Wettestein (1957). Endogenous phytohormones i.e., gibberellins, auxins, cytokinins and total promoters as well as salicylic acid were quantitatively determined in potato shoot at 75 days after planting during season of 2018 using High Performance Liquid Chromatography (HPLC) according to Koshioka et al., (1983) for auxins (IAA), gibberellins, salicylic Acid and abscisic acid (ABA) while cytokinins were determined according to Nicander et al., (1993). 
Table 2. Chemical composition of Spirulina platensis and yeast

\begin{tabular}{|c|c|c|}
\hline Composition & Spirulina & Yeast \\
\hline Protein $(\%)$ & 56.79 & 5.3 \\
\hline Carbohydrates (\%) & 13.60 & 4.7 \\
\hline \multicolumn{3}{|c|}{ Essential amino acids (mg/100 g) } \\
\hline Leucine & 29.11 & 3.09 \\
\hline Phenylalanine & 23.78 & 2.01 \\
\hline Lysine & 19.10 & 2.95 \\
\hline Valine & 18.40 & 2.19 \\
\hline Isoleucine & 14.12 & 2.31 \\
\hline Threonine & 13.59 & 2.09 \\
\hline Histidine & 13.46 & 2.63 \\
\hline Methionine & 5.31 & 0.72 \\
\hline \multicolumn{3}{|c|}{ Non-Essential amino acids (mg/100 g) } \\
\hline Glutamic acid & 47.03 & 2 \\
\hline Arginine & 44.91 & 1.99 \\
\hline Aspartic & 36.69 & 1.33 \\
\hline Alanine & 33.8 & 1.51 \\
\hline Cysteine & 3.30 & 0.23 \\
\hline Tyrosine & 19.74 & 1.49 \\
\hline Serine & 18.43 & 1.59 \\
\hline Glycine & 15.0 & 1.35 \\
\hline Proline & 14.88 & 1.53 \\
\hline \multicolumn{3}{|l|}{ Vitamins (mg/100 g) } \\
\hline Niacin & 15.0 & 0.029 \\
\hline Vitamin B1 & 4.8 & 2.23 \\
\hline Vitamin B2 Riboflavin & 5.5 & 1.33 \\
\hline Vitamin B6 & 0.8 & 1.25 \\
\hline Vitamin B12 & 0.36 & 0.15 \\
\hline Inositol & 70 & 0.26 \\
\hline Folic acid $(\mu \mathrm{g} / 100 \mathrm{~g})$ & 71 & $1.43 \times 10^{3}$ \\
\hline Pantothenic acid & 0.2 & 7.82 \\
\hline
\end{tabular}

All Chemical composition of yeast after Mahmoed (2001) except niacin, folic acid $(\mu \mathrm{g} / 100 \mathrm{~g})$ and Pantothenic acid according to Xi et al., 2019. Amino acids and Vitamins for alga after El-Moataaz et al., (2019) and Liestianty et al. 2019, respectively

\section{Anatomical studies:}

It was intended to carry out a comparative anatomical study on stems and leaves of treated potato plant at 75 days after planting (DAP) during 2018 season and those of the control. Specimens of stems were taken from main stem fifth apical internode while, those of the leaves were taken from the certain leaf of the $4^{\text {th }}$ apical leaf on the main stem. These vegetative specimens were then killed and fixed in F.A.A. $(10 \mathrm{ml}$ formalin, $5 \mathrm{ml}$ glacial acetic acid and $85 \mathrm{ml} \mathrm{70 \%}$ ethyl), washed using 50\% ethyl alcohol, dehydrated in a series of ethyl alcohols 70, 90, 95 and $100 \%$, infiltrated in xylene embedded in paraffin wax with a melting point $60-63^{\circ} \mathrm{C}$, sectioned $12 \mu$ in thickness for stem and $15 \mu$ for the leaf (Sass, 1951), stained with the double stain method (Fast green and safranin), cleared in xylene and mounted in Canada balsam (Johanson, 1940). Four sections of each treatment were microscopically inspected to detect histological manifestations of noticeable responses resulted from treatments. Counts and measurements $(\mu)$ were taken using a micrometer eye piece. Averages readings from 2 slides per treatment were calculated.
At harvest time (120 DAP), tubers yield of five randomly plants/plot were taken for estimating the following characteristics: tubers number and tubers fresh weight $(\mathrm{g})$, in addition to both dry matter (\%) and starch content of tubers according to A.O.A.C. (1990) and specific gravity (\%) as Murphy and Goven (1959). Total nitrogen was determined in the digested tubers dry matter using micro-kjeldahl method according to methods described by Pregl (1945). Also, Phosphorous was estimated according to the method described by Murphy and Riley (1962) modified by John (1970) and Potassium was determined by the flame-optical method as described by Brown and Lilleland (1946). The total protein content was calculated by multiplying the nitrogen $\%$ in tuber with the conversion factor of 6.25 (Ranganna, 1977).

Statistical Analysis: The obtained data in both seasons were subjected to analysis of variance as a simple experiment in a randomized complete block design. The differences between means were evaluated using LSD according to Snedecor and Cocharn (1980). 
Results and Discussion

Vegetative growth and photosynthetic pigments content:

Data in Table (3) clearly show the effect of the foliar spray treatments of benzyladenine, Spirulina alga extract and yeast extract on vegetative growth characteristics of potato plant at 75 DAP during the two growing seasons of 2017 and 2018 compared with the control. In this respect, the solely treatments of $0.6 \%$ algae extract followed by $0.3 \%$ algae extract, $10 \%$ yeast extract and $50 \mathrm{ppm}$ benzyladenine(BA) recorded the highest values of vegetative growth parameters of potato plant. These results are of great interest, as at this stage of growth great simulative effects existed with applied treatments. Hence, that could be prolonged to the advanced stage of the final tubers yield and quality of yielded tubers. In addition, increment of haulm (stems and leaves) fresh and dry weights due to leaves number and total leaf area. Increment of leaf (number and area) could be reflected upon the efficiency of photosynthesis by more assimilates accumulating and high rates of translocation toward tubers. Also, it could be observed that increase of this area was preceded with high number of leaves as well. Moreover, alga extract treatment suggested to participate beneficial roles due to its high levels of organic matter, micro nutrients, vitamins, amino acids and also, rich in growth regulators such as auxins, cytokinin and gibberellins (Blunden, 1991; Crouch and Van Staden, 1994 and Khan et al., 2009) and that may work synergistically at different concentrations (Fornes et al., 2002). Foliar application with algae extract has already been shown to improve plant growth by Featonby and Van Staden (1983), Sivasankari et al., (2006), Abdel Mawgoud et al., (2010) on watermelon, Shehata et al., (2011) on celeriac plant and Abd El-Aal (2012). On the other hand, yeast extract known to have stimulative effects on plant growth due to cytokinins content (Barnett et al., 1990) and improves carbohydrates accumulation (Winkler et al., 1962), cell division and enlargement, protein and nucleic acid synthesis (Fathy and Farid, 1996).

Table 3. Effect of foliar application treatments on morphological traits of potato plant at 75 days after planting during 2017 and 2018 seasons.

\begin{tabular}{|c|c|c|c|c|c|c|c|c|c|}
\hline \multirow{2}{*}{ Item } & \multirow{2}{*}{$\begin{array}{c}\text { Plant } \\
\text { length } \\
(\mathrm{cm})\end{array}$} & \multicolumn{3}{|c|}{ Number plant } & \multirow{2}{*}{$\begin{array}{c}\text { Leaf } \\
\text { area } \\
\left(\mathrm{cm}^{2}\right. \\
\text { plant })\end{array}$} & \multicolumn{2}{|c|}{$\begin{array}{c}\text { Fresh weight (g } \\
\text { plant) }\end{array}$} & \multicolumn{2}{|c|}{$\begin{array}{c}\text { Dry weight (g } \\
\text { plant) }\end{array}$} \\
\hline & & Leaves & $\begin{array}{l}\text { Main } \\
\text { stems }\end{array}$ & $\begin{array}{c}\text { Lateral } \\
\text { stems }\end{array}$ & & Leaves & stems & Leaves & Stems \\
\hline \multicolumn{10}{|c|}{ Season 2017} \\
\hline Control & 50.22 & 82.22 & 3.00 & 20.44 & 2062.6 & 237.96 & 112.62 & 18.84 & 13.02 \\
\hline 25 ppm BA & 52.00 & 99.13 & 3.00 & 21.33 & 2855.5 & 258.60 & 121.30 & 20.54 & 16.42 \\
\hline 50 ppm BA & 57.32 & 100.22 & 3.00 & 23.44 & 3003.8 & 260.41 & 122.62 & 24.31 & 17.40 \\
\hline $5 \%$ Yeast & 56.21 & 100.28 & 3.00 & 21.11 & 2509.4 & 251.57 & 118.94 & 20.08 & 15.09 \\
\hline $10 \%$ Yeast & $\mathbf{5 9 . 5 0}$ & 104.50 & 4.22 & 24.99 & 3282.1 & 261.35 & 125.01 & 24.52 & 18.10 \\
\hline $0.3 \%$ Algae & 63.42 & 102.72 & 3.33 & 25.10 & 3360.3 & 275.18 & 126.54 & 24.58 & 19.25 \\
\hline $0.6 \%$ Algae & 62.22 & 106.11 & 4.10 & 26.22 & 3387.2 & 276.33 & 126.91 & 25.86 & 19.77 \\
\hline L.S.D. $5 \%$ & 0.96 & 0.92 & 0.11 & 1.97 & 156.3 & 5.99 & 5.83 & 1.48 & 0.53 \\
\hline \multicolumn{10}{|c|}{ Season 2018} \\
\hline Control & 45.77 & 79.22 & 2.83 & 17.99 & 2110.7 & 220.15 & 100.12 & 19.34 & 14.28 \\
\hline 25 ppm BA & 53.77 & 91.22 & 3.11 & 22.66 & 2980.3 & 251.43 & 116.12 & 21.25 & 17.06 \\
\hline 50 ppm BA & 59.10 & 98.33 & 3.22 & 23.33 & 2989.8 & 253.35 & 116.55 & 21.35 & 18.03 \\
\hline $5 \%$ Yeast & 55.33 & 95.11 & 3.22 & 22.21 & 2665.1 & 246.07 & 109.36 & 22.82 & 17.02 \\
\hline $10 \%$ Yeast & 60.88 & 102.33 & 4.21 & 24.33 & 3179.2 & 254.29 & 117.05 & 24.27 & 18.05 \\
\hline $0.3 \%$ Algae & 62.16 & 101.11 & 3.44 & 24.99 & 3268.4 & 260.32 & 120.26 & 24.95 & 18.99 \\
\hline $0.6 \%$ Algae & 61.88 & 104.33 & 3.66 & 25.55 & 3408.6 & 278.28 & 124.09 & 26.02 & 20.07 \\
\hline L.S.D. $5 \%$ & 0.92 & 1.66 & 0.14 & 2.76 & 145.3 & 3.45 & 2.64 & 2.40 & 0.54 \\
\hline
\end{tabular}

Improving growth and overall quality of horticultural plants by yeast application was reported by Gomaa et al., (2005), Hussain and Khalaf (2007), Ahmed et al., (2011) and El-Desouky et al., (2011) and Taha and Helal (2019). As for benzyladenine (BA), it is regulating various processes i.e. plant growth and development including cell division and differentiation, leaf expansion and nutrient mobilization. It is also implicated in secondary metabolites synthesisand vascular development (Duszka et $\boldsymbol{a l}$., 2009). BA exogenously application result in an increasing plant height (Letham, 1969), leaf area (Abdullah et al., 1986) and branching (Hrotko et al., 1996). Data in Table (4) show that all the applied treatments significantly increased photosynthetic pigments content, i.e, chlorophyll a, b, $\mathrm{a}+\mathrm{b}$ and carotenoids compared with the control at 75 DAP during the two growing seasons of 2017 and 2018. Results also showed that foliar spraying with $0.6 \%$ Spirulina extract showed a maximum increment in chlorophyll a, chlorophyll b and total chlorophyll by $16.7 \& 36.0 \%, 53.2 \& 86.0 \%$ and $28.2 \& 52.7 \%$, respectively over the corresponding untreated plants (control) in $1^{\text {st }}$ and $2^{\text {nd }}$ seasons, respectively followed 
by $0.3 \%$ Spirulina extract and $10 \%$ yeast extract, in descending order. On the other hand, low concentration $(25 \mathrm{ppm})$ of benzyladenine extracts exhibited slightly decrease effects in chlorophyll a, chlorophyll $\mathrm{b}$ and total chlorophyll. On the contrary, low concentration ( $25 \mathrm{ppm}$ ) of benzyladenine extracts showed significant increment on carotenoid by $55.3 \&$ $55.8 \%$ over the control followed by $5 \%$ yeast and 50 ppm benzyladenine in descend order at both seasons.

Table 4. Effect of foliar application treatments on photosynthetic pigments content of potato plant at 75 days after planting during 2017 and 2018 seasons.

\begin{tabular}{|c|c|c|c|c|c|c|c|c|}
\hline \multirow{2}{*}{ Item } & \multirow{2}{*}{ Control } & \multicolumn{2}{|c|}{ Benzyladenine (BA) } & \multicolumn{2}{|c|}{ Yeast extract } & \multicolumn{2}{|c|}{ Alga extract } & \multirow{2}{*}{$\begin{array}{c}\text { L.S.D. } \\
5 \%\end{array}$} \\
\hline & & 25 ppm & 50 ppm & $5 \%$ & $10 \%$ & $0.3 \%$ & $0.6 \%$ & \\
\hline \multicolumn{9}{|c|}{2017} \\
\hline \multirow{3}{*}{$\begin{array}{l}\text { Chlorophyll } \\
\qquad\left(\mathrm{mg} \mathrm{g}^{-1}\right)\end{array}$} & 1.02 & 1.04 & 1.14 & 1.11 & 1.15 & 1.17 & 1.19 & 0.01 \\
\hline & 0.47 & 0.53 & 0.62 & 0.57 & 0.66 & 0.71 & 0.72 & 0.04 \\
\hline & 1.49 & 1.57 & 1.76 & 1.68 & 1.81 & 1.88 & 1.91 & 0.05 \\
\hline Carotenoids ( $\mathrm{mg} \mathrm{g}^{-1}$ ) & 0.47 & 0.73 & 0.68 & 0.7 & 0.64 & 0.66 & 0.59 & 0.04 \\
\hline \multicolumn{9}{|c|}{2018} \\
\hline \multirow{4}{*}{$\begin{array}{lc}\text { Chlorophyll } & \text { (a) } \\
\left(\mathrm{mg} \mathrm{g}^{-1}\right) & (\mathbf{b}) \\
\text { Carotenoids }\left(\mathrm{mg} \mathrm{g}^{-1}\right)\end{array}$} & 0.86 & 0.91 & 1.09 & 1.13 & 1.15 & 1.15 & 1.17 & 0.03 \\
\hline & 0.43 & 0.57 & 0.61 & 0.64 & 0.68 & 0.73 & 0.8 & 0.08 \\
\hline & 1.29 & 1.48 & 1.7 & 1.77 & 1.83 & 1.88 & 1.97 & 0.11 \\
\hline & 0.52 & 0.81 & 0.67 & 0.7 & 0.59 & 0.58 & 0.56 & $\mathbf{0 . 0 3}$ \\
\hline
\end{tabular}

These results are of great interest, because they are lightly considered direct reason for the higher dry matter production and distribution in potato plants shoots as affected by different applied treatments. In this respect, total carbohydrate increase with different applied treatments consider as a direct result of increasing both photosynthesis rate and efficiency. Our results go on line with those reported that these treatments are implicated in the synthesis of secondary metabolites, influences chlorophyll biosynthesis and chloroplast differentiation (Duszka et al., 2009 for benzyiadenine; Fathy and Farid, 1996 and ElDesouky et al., 2011 for yeast and El-Sheekh and ElSaied, 1999; Abd El-Aal, 2012 and Osman, 2015 for algae effectiveness).

\section{Endogenous phytohoromones}

Data in Table 5 show endogenous phytohormones content changes i.e., Gibberellic Acids $\left(\mathrm{GA}_{3}\right)$, Auxins , Cytokinins, Abscisic Acid (ABA), and Salicylic Acid of potato (Solanum tuberosum L.) plant at 75 days after planting during 2018 season sprayed with different used promoting treatments compared with the control which greatly improved morphological, metabolical and histological performances of potato plant as apparent from results obtained in the present study.

As for auxins level, it was extremely increased in potato shoots with different treatments compared with control plants. In this respect, the most superior treatments were the algae extract at $0.6 \%$ for IAA followed by benzyladenine (BA) at $25 \mathrm{ppm}$ and $10 \%$ yeast extract, whereas both $5 \%$ yeast extract and 50 ppm benzyladenine were the highest effective treatment on IBA followed by $0.3 \%$ algae extract, 25 ppm benzyladenine and $10 \%$ yeast extracts in descending order which highly increased total auxins compared with control and other treatments. With regard to gibberellins level, data in the same Table (5) also clearly illustrate that the level of gibberellin likesubstances in potato (Solanum tuberosum L.) shoots was increased with algae extract at different used treatments as compared with the control plants but it mostly increased in cases of algae extract at $0.6,0.3 \%$ and low concentrates of benzyladenine and yeast extract treatments.

Furthermore, the level of cytokinins positively responded to the different assigned treatments. Since, the activity was the lowest in the control. Generally, these phytohormones those promote growth aspects (i.e., growth promoters, auxins, gibberellin and cytokinin) were highly increment with different assigned treatments compared with the control.

Here the treatments of algae extract at $0.6,0.3 \%$, yeast extract at $5 \%$ and benzyl adenine at $50 \mathrm{ppm}$, respectively gave the highest values activity of promoting phytohormones level. Also, endogenous hormones increase in potato plants obtained in the present study could be interpret the obtained modifications in different studied histological features (Table 6) and the improvement of growth (Table 3) and tubers yield characteristics (Table 7). For example, increasing cytokinins could be in favor of increasing the number of formed lateral stems and that could also increase transverse growth on the account of longitudinal one as well as increasing of sink organs (tubers) ability to accumulate and storage more assimilates. With regard to the growth inhibitor, abscisic acid level reduced with various assigned treatments compared with the control, but the reduction was more obvious with treatments of 25 ppm benzyladenine, 5\% yeast extract, $50 \mathrm{ppm}$ benzyladenine, $10 \%$ yeast extract, $0.6 \%$ and $0.3 \%$ algae extracts in descending order. 
Table 5. Effect of foliar application treatments on endogenous phytohormones content ( $\mu \mathrm{g} \mathrm{g}^{-1}$ fwt.) of potato shoots at 75 days after planting during 2018 season.

\begin{tabular}{|c|c|c|c|c|c|c|c|c|c|}
\hline \multirow{2}{*}{\multicolumn{3}{|c|}{ Item }} & \multirow{2}{*}{ Control } & \multicolumn{2}{|c|}{ Benzyladenine } & \multicolumn{2}{|c|}{ Yeast extract } & \multicolumn{2}{|c|}{ Algae extract } \\
\hline & & & & $25 \mathrm{ppm}$ & 50 ppm & $5 \%$ & $10 \%$ & $0.3 \%$ & $0.6 \%$ \\
\hline \multirow{7}{*}{ Promoters } & \multirow{3}{*}{ Auxins } & IAA & 9.26 & 14.11 & 7.75 & 6.63 & 11.81 & 8.1 & 16.98 \\
\hline & & IBA & 60.59 & 94.34 & 212.66 & 212.91 & 79.02 & 187.79 & - \\
\hline & & Total & 69.85 & 108.45 & 220.41 & 219.54 & 90.83 & 195.89 & 16.98 \\
\hline & \multicolumn{2}{|c|}{ Gibberellic } & 207.52 & 331.51 & 213.29 & 248.85 & 110.33 & 219.42 & 414.69 \\
\hline & \multicolumn{2}{|c|}{ Cytokinins } & 189.35 & 319.97 & 629.68 & 673.47 & 708.25 & 735.2 & 841.99 \\
\hline & \multicolumn{2}{|c|}{ Total promoters } & 486.72 & 759.93 & 1063.38 & 1141.86 & 909.41 & 1150.51 & 1273.66 \\
\hline & \multicolumn{2}{|c|}{ Increment (\%) } & 0.0 & 56.13 & 118.48 & 134.6 & 86.84 & 136.56 & 161.68 \\
\hline \multirow{2}{*}{ Inhibitors } & \multirow{2}{*}{\multicolumn{2}{|c|}{$\begin{array}{c}\text { Abscisic acid } \\
\text { Increment }(\%)\end{array}$}} & 2.56 & 0.76 & 1.4 & 1.22 & 1.41 & 2.08 & 1.64 \\
\hline & & & 0.0 & -70.3 & -45.3 & -52.3 & -44.9 & -18.8 & -35.9 \\
\hline \multirow{2}{*}{ SA } & \multirow{2}{*}{\multicolumn{2}{|c|}{$\begin{array}{c}\text { Content } \\
\text { Increment }(\%)\end{array}$}} & 42 & 96.46 & 30.45 & 35.55 & 58.13 & 48.58 & 71.55 \\
\hline & & & 0.0 & 129.67 & -27.5 & -15.4 & 38.4 & 15.67 & 70.36 \\
\hline
\end{tabular}

IAA: 3-Indole acetic acid IBA: Indole 3 butyric acid SA: Salicylic acid \% Increment: \% Relative to control

Moreover, salicylic acid level Table (5) was increased with the different assigned treatments compared with the control. In this respect, these results being of great interest for interpreting each of the obtained vigorous growth and the great tubers yield of potato plant attained in the present study.

Our results are in harmony with those reported by Davies (1995) and Duszka et al. (2009). They concluded that benzyladenine is an important plant hormone regulating various processes of plant growth and development including cell division and differentiation, enhancement of leaf expansion and nutrient mobilization. Many studies were conducted in Egypt (Shady, 1978; Fathy and Farid, 1996; Gomaa et al., 2005; Hussain and Khalaf, 2007; Ahmed et al., 2011 and El-Desouky et al., 2011) and other countries (Winkler et al., 1962; Barnett et al., 1990) on yeast treatments. They suggested to participate a beneficial role due to its cytokinins, auxins and gibberellins content, improves carbohydrates accumulation and contents of protective agent, i.e., sugars, proteins and amino acids and also several vitamins in addition to its stimulatory effects on cell division and enlargement, protein and nucleic acid synthesis. As for Algae extract application for different crops, Blunden (1991), Crouch and Van Staden (1994), Khan et al., (2009) and Abd El-Aal (2012) stated that it is a great importance due to it contains high levels of organic matter, micro elements ( $\mathrm{Fe}, \mathrm{Cu}, \mathrm{Zn}, \mathrm{Co}, \mathrm{Mo}, \mathrm{Mn}$, and $\mathrm{Ni}$ ), vitamins, amino acids and growth regulators such as auxins, cytokinin and gibberellins.

\section{Anatomical studies:}

Data in Table 6 and Figs. (1 and 2) show the effect of applied treatments on the mean counts and measurements in microns of certain histological features of the main stem and leaf of potato plant (Solanum tuberosum L.) at 75 days after planting during 2018 season.

\section{Stem anatomy:}

Table 6 and Fig. 1 show that different applied treatments increased the stem diameter compared with control. This increase reached its maximum values with algae extract at $0.6,0.3 \%$, yeast extract at $10 \%$ and benzyladenine at $50 \mathrm{ppm}$, respectively compared with the stem diameter of the control. Also, it could be noticed that increase of the stem diameter was reversed upon different tissues comprising the whole section. Since, thickness of each cuticle layer, epidermis, cortex (collenchyma and parenchyma tissues) and pith parenchyma layers, as well as the dimensions of vascular bundles. Moreover, thickness of phloem tissue, cambial region and of xylem tissue, number of xylem vessels vascular cylinder and diameter of the widest xylem vessel were greatly increased compared with the control. In general, the stimulatory effects of applied treatments upon the anatomy features of treated plants could be attributed to the effect upon cambium activity. Increment of cambium activity could mainly attributed to the increase of endogenous hormones level especially cytokinins and auxins. These results are line with the findings of Sotiropoulos et al., (2002) and Abd ElAal and Eid (2017). Of interest to note that these positive responses of different anatomical aspects to treatments were completely reversed upon vegetative and tubers growth of treated plants. So, present study revealed those increases of xylem tissue, i.e., the route of mineral nutrients and water translocation from roots to leaves and the phloem tissue i.e., the pathway of different assimilates from leaves to tuber plant sinks. Thereby, improvement of translocation events directly could be considered a direct reason for increment the final tubers yield.

Leaf anatomy:

Data in Table 6 and Fig. 2 clearly indicate the effect of applied treatments upon different anatomical features of potato leaves. In this respect, most of the 
studied features of leaf anatomy were enlarged with different applied treatments. Among these anatomical features were the most important ones, i.e., thickness of midrib, length \& width of vascular bundle, thickness of phloem \& xylem tissues and number of xylem vessels in vascular bundle as well as the leaf blade thickness. With regard to the blade thickness, it was increased with different used treatments to reach its maximum with algae extract at $0.6,0.3 \%$, yeast extract at $10 \%$ and benzyladenine at $50 \mathrm{ppm}$, respectively which were the most effective treatments in this order compared with the control and other treatments. Of interest, to note that mesophyll increasing belong to that increase of each of palisade and spongy tissue thickness. Since, the two components were increased with all applied treatments but reached their maximum as other traits with algae extract at $0.6 \%$ treatment. With regard to midrib anatomical features, increment in the midrib thickness in response to different applied treatments attributed to the increase in histological features such as thickness of both uppermost and lower most collenchyma tissues; lower most parenchyma tissue and dimensions of vascular bundle as well as thickness of phloem and xylem tissues as well as number and diameter of xylem vessels in the vascular bundle. These increases were further obvious with the algae extract at $0.6,0.3 \%$ and yeast extract at $10 \%$ treatments. The mentioned results specially conductive tissues (xylem \& phloem) increment are also of great importance because they could be involved in the understanding why vigorous growth and high yielded tubers existed with different applied treatments specially with algae extract at $0.6 \%$ due to different promoters hormones (Table 5) of these studied extracts and that shoot branching from axillary buds is regulated by a network of inhibitory and promotive forces, which includes hormones (Domagalska and Leyser, 2011).

Table 6. Mean counts and measurements of histological features of potato (Solanum tuberosum L.) stem and leaf at 75 days after planting during 2018 season.

\begin{tabular}{|c|c|c|c|c|c|c|c|}
\hline \multirow{2}{*}{$\begin{array}{c}\text { Treatment } \\
\text { Histological Characteristics (micron) }\end{array}$} & \multirow{2}{*}{ Control } & \multicolumn{2}{|c|}{ Benzyladenine } & \multicolumn{2}{|c|}{ Yeast extract } & \multicolumn{2}{|c|}{ Alga extract } \\
\hline & & 25 ppm & $50 \mathrm{ppm}$ & $5 \%$ & $10 \%$ & $0.3 \%$ & $0.6 \%$ \\
\hline \multicolumn{8}{|c|}{ Stem } \\
\hline Stem diameter & 3482 & 3851 & 4252 & 4182 & 4595 & 5145 & 5138 \\
\hline Cuticle layer thickness & 7 & 5 & 4 & 5 & 5 & 6 & 6 \\
\hline Epidermis thickness & 15 & 14 & 15 & 14 & 14 & 16 & 15 \\
\hline Collenchyma thickness & 183 & 175 & 212 & 176 & 231 & 209 & 217 \\
\hline Parenchyma thickness & 207 & 293 & 316 & 260 & 358 & 339 & 382 \\
\hline Cambial region thickness & 14 & 16 & 23 & 16 & 18 & 21 & 22 \\
\hline Phloem thickness & 176 & 193 & 208 & 181 & 217 & 235 & 280 \\
\hline Xylem thickness & 413 & 469 & 611 & 549 & 616 & 627 & 670 \\
\hline Xylem rows No. vascular cylinder & 185 & 231 & 216 & 282 & 261 & 240 & 227 \\
\hline Xylem vessels NO. row & 9 & 13 & 12 & 11 & 12 & 10 & 13 \\
\hline Widest xylem vessel diameter & 34 & 35 & 32 & 34 & 30 & 31 & 32 \\
\hline Parenchymatous pith thickness & 1452 & 1521 & 1474 & 1780 & 1677 & 2239 & 1954 \\
\hline \multicolumn{8}{|l|}{ 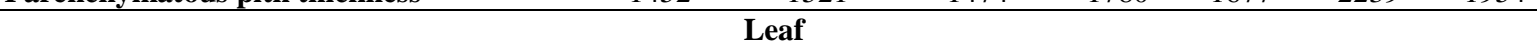 } \\
\hline Upper epidermis thickness & 17 & 18 & 19 & 17 & 20 & 18 & 19 \\
\hline Lower epidermis thickness & 14 & 14 & 15 & 13 & 14 & 13 & 15 \\
\hline Palisade tissue thickness & 111 & 122 & 139 & 119 & 118 & 121 & 132 \\
\hline Spongy tissue thickness & 226 & 243 & 312 & 235 & 258 & 287 & 294 \\
\hline Blade thickness & 388 & 429 & 407 & 407 & 435 & 462 & 485 \\
\hline Upper collenchyma thickness & 427 & 406 & 481 & 315 & 502 & 360 & 413 \\
\hline Lower collenchyma thickness & 310 & 318 & 219 & 223 & 349 & 314 & 275 \\
\hline Phloem thickness & 113 & 147 & 165 & 139 & 166 & 179 & 186 \\
\hline Xylem tissue thickness & 394 & 415 & 461 & 421 & 570 & 456 & 477 \\
\hline Xylem rows number & 11 & 13 & 15 & 14 & 15 & 16 & 16 \\
\hline Widest xylem vessel thickness & 35 & 35 & 37 & 34 & 41 & 36 & 38 \\
\hline Midrib vascular bundle length & 503 & 523 & 669 & 562 & 713 & 717 & 790 \\
\hline Midrib vascular bundle width & 752 & 780 & 847 & 837 & 911 & 844 & 901 \\
\hline Leaf midrib thickness & 2557 & 2644 & 2905 & 2552 & 3270 & 2832 & 3098 \\
\hline
\end{tabular}

Also, developmental stages of bud outgrowth are likely associated with checkpoints for feedback regulation and hence enable the homeostasis of shoot number. These stages may also account for the observation that buds at different locations show different responses to signals such as auxin and cytokinin (Dun et al 2006). On the other hand, Cline (1994) stated that auxin inhibit axillary bud outgrowth whereas cytokinins promote it while, endogenous hormone levels has demonstrated powerful effects of auxin and cytokinin on axillary bud outgrowth. In general, these positive alterations in stem and leaf anatomy of potato plant treated with applied treatments led to vigorous growth and enhancement of tubers yield of treated plants. 


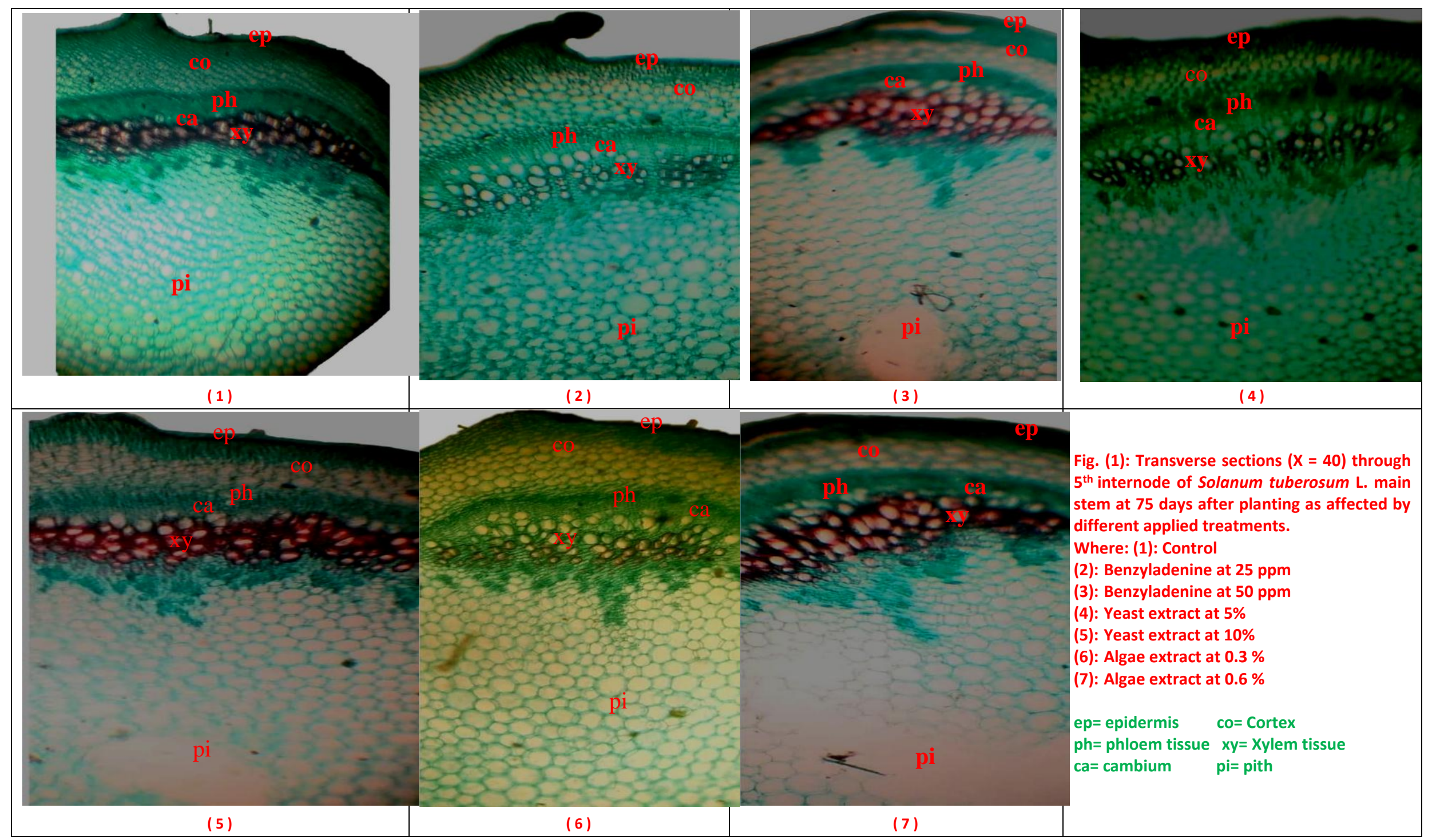




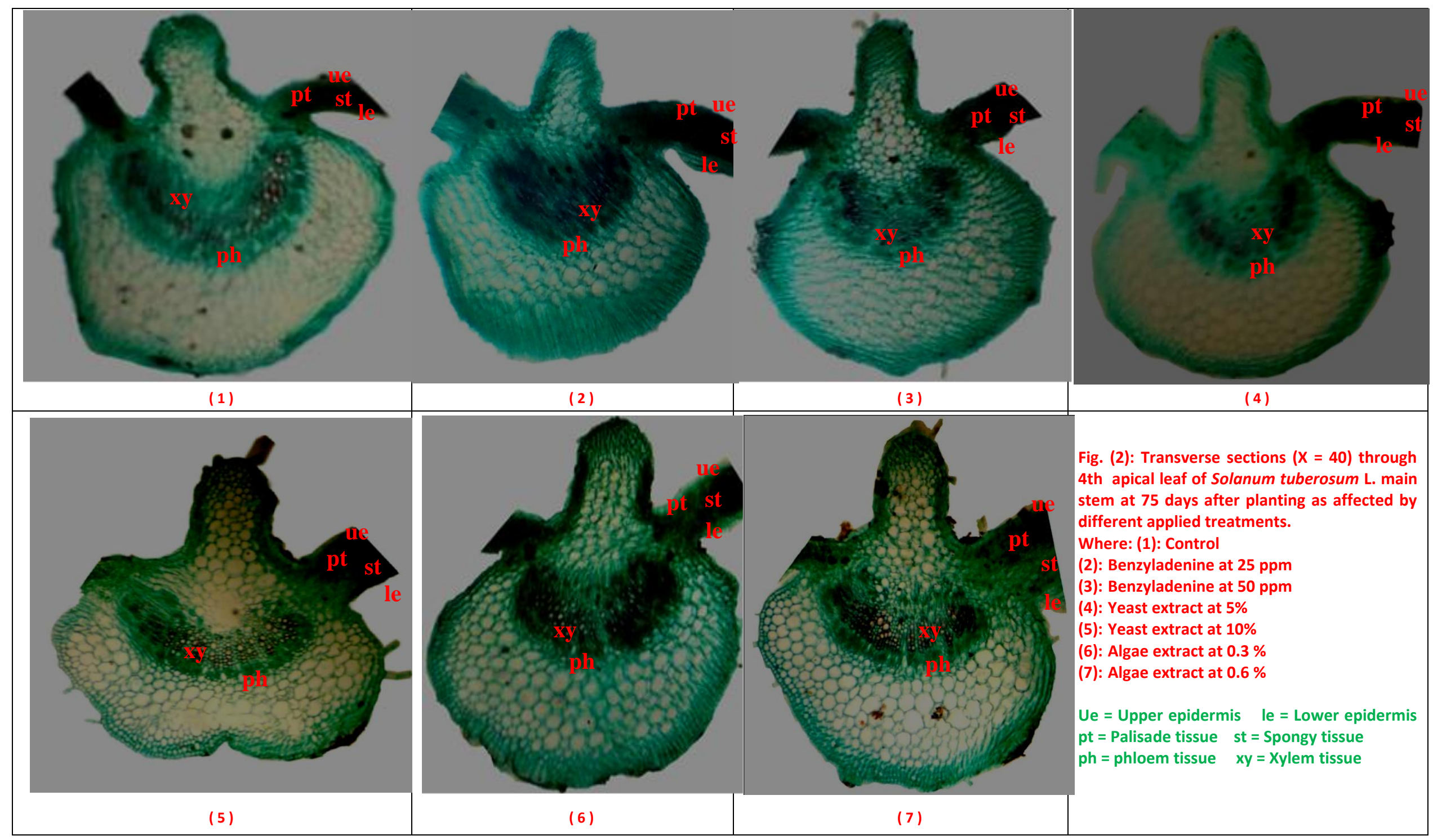


That as well mentioned afterwards reversed upon high increases in the final tubers yield. Also, the previously mentioned and discussed results of potato leaf anatomy of treated plants, reveal that increasing of leaf anatomy features compared with control confirmed by vigorous growth of potato was positively along with minerals content (N, P and K), photosynthesis pigments and carbohydrates content (Abd El-Aal and Eid, 2017).

\section{Tubers yield and chemical constituents:}

Data in Table (7) obviously show that tubers yield and its components of potato were highly increased as affected by different applied treatments. All applied treatments significantly increased tubers number/plant, tubers fresh weight/plant and tubers total yield/feddan as well as tubers dry matter compared with the control during the two growing seasons. Same data revealed that the highest total tubers yield were obtained with algae extract at $0.6,0.3 \%$, yeast extract at $10 \%$ and benzyladenine at $50 \mathrm{ppm}$, respectively which were the most effective treatments in this order compared with the control and other treatments. These results are of great interest because they mean that used treatments increased dry matter accumulation in tubers yield. However, the stimulation of dry matter production considered as a direct result of that vigorous growth including the photosynthetic area and photosynthetic pigments in leaves of potato plants during different stages of growth. Our results are in agreement with those of Rama Rao (1991), Awad et al., (2006), Ahmed et al., (2011), Fawzy et al., (2012 a, b), Mansowr (2012) and Osman (2015) and Taha and Helal (2019).

Table 7. Effect of foliar application treatments on tuber yield components of potato plant during 2017 and 2018 seasons.

\begin{tabular}{|c|c|c|c|c|c|}
\hline \multirow[t]{2}{*}{ Item } & $\begin{array}{c}\text { Tubers number } \\
\text { plant }\end{array}$ & $\begin{array}{l}\text { Tubers fresh weight } \\
\text { (g plant) }\end{array}$ & $\begin{array}{l}\text { Tubers dry } \\
\text { matter \% }\end{array}$ & $\begin{array}{c}\text { Tubers specific } \\
\text { gravity }\end{array}$ & $\begin{array}{l}\text { Tubers total yield } \\
\text { (ton feddan) }\end{array}$ \\
\hline & \multicolumn{5}{|c|}{ Season 2017} \\
\hline Control & 7.66 & 482.85 & 18.41 & 1.061 & 11.986 \\
\hline 25 ppm Benzyl-Ad & 5.55 & 539.33 & 18.62 & 1.061 & 13.013 \\
\hline 50 ppm Benzyl-Ad & 8.55 & 564.77 & 19.71 & 1.073 & 15.016 \\
\hline $5 \%$ Yeast & 8.33 & 539.55 & 19.82 & 1.072 & 13.012 \\
\hline $10 \%$ Yeast & 9.22 & 597.16 & 18.72 & 1.074 & 15.765 \\
\hline $0.3 \%$ Algae & 10.00 & 621.58 & 19.93 & 1.081 & 15.958 \\
\hline $0.6 \%$ Algae & 10.11 & 652.83 & 20.58 & 1.083 & 16.873 \\
\hline L.S.D. 5\% & 1.28 & 18.56 & 0.97 & N.S. & 0.218 \\
\hline \multicolumn{6}{|c|}{ Season 2018} \\
\hline Control & 8.56 & 476.18 & 17.07 & 1.060 & 11.693 \\
\hline 25 ppm Benzyl-Ad & 9.77 & 544.66 & 19.09 & 1.067 & 12.259 \\
\hline 50 ppm Benzyl-Ad & 9.52 & 601.19 & 19.59 & 1.067 & 14.648 \\
\hline $5 \%$ Yeast & 9.22 & 499.57 & 18.41 & 1.060 & 13.652 \\
\hline $10 \%$ Yeast & 10.10 & 632.19 & 19.75 & 1.071 & 14.865 \\
\hline $0.3 \%$ Algae & 10.52 & 655.67 & 20.05 & 1.074 & 15.576 \\
\hline $0.6 \%$ Algae & 11.04 & 664.12 & 20.15 & 1.081 & 16.459 \\
\hline L.S.D. 5\% & 1.10 & 11.94 & 0.81 & N.S. & 0.612 \\
\hline
\end{tabular}

Regarding to tubers chemical constituents, data presented in Table (8) show that most of applied treatments highly increased determined bioconstituents content i.e., $\mathrm{N}, \mathrm{P}, \mathrm{K}$, crude protein and starch $(\%)$ in the marketable potato tubers. In this respect, the most effective treatment algae extract at $0.6,0.3 \%$ and yeast extract at $10 \%$. The above mentioned results evidently indicated that the applied treatments were greatly increased the ability of potato tubers as sink organs having high nutritive value, i.e., it increased their validity for human consumption.

Also, the same data clearly indicate that increasing the minerals content in potato tubers was positively and greatly in line with minerals and bioconstituents composition of vegetative organs (i.e., leaves), which induce the most active metabolical cases. Such results indicate the stimulative effect of the applied treatments to enhance internal metabolical mechanism of potato plant towards maximizing its growth and productivity. The obtained positive bioconstituents responses are the result of increasing leaf area and its reversion upon increasing the net photosynthesis per unit of leaf area. Our results were in line with those reported by Davies (1995) and Duszka et al., (2009). They concluded that benzyladenine is regulating various processes of plant i.e., enhancement of nutrient mobilization, increases field crops yield and improves crop quality in addition to implicate in the synthesis of secondary metabolites. For yeast treatment suggested to participate a beneficial role during yield due to its cytokinins content, improves carbohydrates accumulation. Add to its contents of protective agent, i.e., sugars, proteins and amino acids and also several vitamins (Shady, 1978). Improving yield and overall quality of horticultural plants by yeast application was reported by Winkler et al., (1962), Barnett et al., (1990), Gomaa et al., (2005), Hussain and Khalaf (2007), Ahmed et al., (2011) and El-Desouky et al., (2011). As for Algae extract, application for different crops is a great importance due to it contains high levels of organic matter, micro elements ( $\mathrm{Fe}, \mathrm{Cu}, \mathrm{Zn}, \mathrm{Co}, \mathrm{Mo}$, $\mathrm{Mn}$, and $\mathrm{Ni}$ ), vitamins, amino acids and also, growth regulators such as auxins, cytokinin and gibberellins 
(Blunden, 1991; Crouch and Van Staden, 1994 and Khan et al., 2009). The beneficial effects of algae extract is a result of many components that may work synergistically at different concentrations Fornes $\boldsymbol{e t}$ al., (2002). Foliar application with algae extract has already been shown to enhance plant yield and its quality were stated by Featonby and Van Staden (1983), Sivasankari et al., (2006), Abdel Mawgoud et al., (2010), Shehata et al., (2011), Abd El-Aal (2012) and Osman (2015).

Table 8. Effect of foliar application treatments on tuber chemical constituents \% of potato plant during 2017 and 2018 seasons.

\begin{tabular}{|c|c|c|c|c|c|}
\hline Item & $\mathbf{N}$ & $\mathbf{P}$ & $\mathbf{K}$ & Crude protein & Starch \\
\hline \multicolumn{6}{|c|}{ Season 2017} \\
\hline Control & 2.48 & 0.32 & 3.52 & 15.50 & 10.01 \\
\hline 25 ppm Benzyladenine & 2.68 & 0.35 & 3.55 & 16.75 & 10.90 \\
\hline 50 ppm Benzyladenine & 2.93 & 0.36 & 3.71 & 18.31 & 11.12 \\
\hline $5 \%$ Yeast extract & 2.98 & 0.37 & 3.82 & 18.62 & 11.70 \\
\hline $10 \%$ Yeast extract & 2.61 & $\mathbf{0 . 3 8}$ & 3.54 & 16.31 & 11.03 \\
\hline $0.3 \%$ Algae extract & 2.80 & 0.33 & 3.58 & $\mathbf{1 7 . 5 0}$ & 10.04 \\
\hline $0.6 \%$ Algae extract & 2.06 & 0.25 & 3.17 & 12.87 & 8.94 \\
\hline L.S.D. 5\% & 0.11 & 0.01 & 0.06 & 0.68 & 1.53 \\
\hline \multicolumn{6}{|c|}{ Season 2018} \\
\hline Control & 2.44 & 0.29 & 3.41 & 15.25 & 9.77 \\
\hline 25 ppm Benzyladenine & 2.58 & 0.32 & 3.51 & 16.12 & 10.34 \\
\hline 50 ppm Benzyladenine & 2.73 & 0.33 & 3.56 & 17.06 & 11.23 \\
\hline $5 \%$ Yeast extract & 2.85 & 0.34 & 3.57 & 17.81 & 11.31 \\
\hline $10 \%$ Yeast extract & 2.50 & 0.35 & 3.47 & 15.62 & 11.15 \\
\hline $0.3 \%$ Algae extract & 2.60 & $\mathbf{0 . 3 2}$ & 3.54 & 16.25 & $\mathbf{1 0 . 0 6}$ \\
\hline 0.6\% Algae extract & 2.01 & 0.26 & 3.17 & 12.56 & 8.57 \\
\hline L.S.D. 5\% & 0.03 & N.S. & N.S. & 0.47 & 0.59 \\
\hline
\end{tabular}

\section{Conclusion}

We recommend through this study that it is possible to spray with algae extract at 0.6 or $0.3 \%$ as well as yeast extract at $10 \%$ to increase the number of lateral stems which increasing the transverse growth on the account of longitudinal one as well as, increasing of sink organs (tubers) ability to accumulate and storage more assimilations, stimulate and improve of vegetative growth characteristics consequently, increasing both of yield and quality of potato tubers.

\section{References}

A.O.A.C. (1990): Official Methods of Analysis of Association of Official Analytical Chemists. Pub. INC. Suite 400, 22201 USA $15^{\text {th }}$ Ed. 62, 63, 236, 877 and 878.

Abd El-Aal, M. M. M. (2012): Response of Ananas Melon to foliar spray with some natural Extracts.Res. J. Agric. \& Biol. Sci., 8(2): 201-212.

Abd El-Aal, M. M. M. and R. S. M. Eid (2017): Optimizing growth, seed yield and quality of soybean (Glycine max L.) plant using growth substances. Asian Research Journal of Agriculture, 6 (3): 1-19.

Abdel-Aal, Z. S., A. A. Khalf-Alla, M. Al-Shal and M. Abd-al-Qader (1977): Vegetables Production, Part 2. Dar Al-Madboal. Al-Jadida, Publisher Alexandria, A.R.E., 15-57.

Abdel-Mawgoud, A. M. R., A. S. Tantawy, M. M. Hafez and H. A. M. Habib (2010). Seaweed extract improves growth, yield and quality of different watermelon hybrids, Res. J. of Agric. and Biol. Sci., 6, (2) : 161-186.
Abdullah, A. A., R. Grace and M. M. Yeoman (1986): Rapid micropropagation of Calabrian pine from primary and secondary buds on shoot explants. Can. J. Forest Res., 16: 637-641.

Ahmed, A. A., M. M. H. El-Baky, M. F. Zaki and F. S. EL-Aal (2011): Effect of foliar application of active yeast extract and zinc on growth, yield and quality of potato plant (Solanum tuberosum L.). Journal of Applied Sciences Research. 7 (12): 2479-2488.

Awad, El. M. M, N. S. Youssef and Z. S. El-Shal (2006): Effect of foliar spraying seaweed extracts and inorganic fertilizers levels on growth, yield and quality of potato crop. J. Agric. Sci. Mansoura Univ. 31(10): 6549-6559.

Bach, S., R. Y. Yada, B. Bizimungu and J. A. Sullivan (2012): Genotype by environment interaction effects on fibre components in potato (Solanum tuberosum L.). Euphytica 187, 77-86. doi: 10.1007/s10681-012-0734-9

Barnett, J. A., R. W. Payne and D. Yarrow (1990): Yeasts, characteristics and identification. Cambridge Univ. Press. Published by the press syndicate of the Univ. of Cambridge. Camb. CB2 IBR, 40 West 20th St., pp. 999.

Blunden, G. (1991): Agricultural uses of seaweeds and seaweed extracts. In Guiry MD, Blunden G (eds) Seaweed resources in Europe. Uses and potential. Wiley, Chichester, 65-81

Brown, J. D. and O. Lilleland (1946): Rapid determination of potassium and sodium in plant material and soil extracts by phlame photometry. Proc. Amer. Soc Hort. Sci. 48, 341-345 
Cline M. G. (1994). The role of hormones in apical dominance. New approaches to an old problem in plant development. Physiologia plantarum, 90(1): 230-237

Crouch, I. J. and J. Van Staden (1994): Commercial seaweed products as Biostimulants in horticulture J. Home and Consumer Horticulture, 1: 19-76.

Davies, P. J. (1995): Plant Hormones: Physiology, Biochemistry and Molecular Biology. Kluwer Academic Publishers, Dordrecht, The Netherlands., pp: 833.

Domagalska M. A. and O. Leyser (2011). Signal integration in the control of shoot branching. Nat Rev Mol Cell Biol., 12(4):211-21.

Dun E. A., B. J. Ferguson and C. A. Beveridge (2006). Apical Dominance and Shoot Branching. Divergent Opinions or Divergent Mechanisms?. Plant Physiology, 142: 812-819

Duszka, K., B. F. C. Clark, F. Massino and J. Barciszewski (2009): Biological activities of kinetin. In: Ramawat KG (eds) Herbal Drugs: Ethnomedicine to Modern Medicine. Verlag Berlin Heidelberg, Berlin, pp: 369- 380.

El-Desouky, S. A. , F. H. Ismaeil, A. L. Wanas E-S. L. Fathy and M. M. AbdEl-All (2011): Effect of yeast extract, amino acids and citric acid on physioanatomical aspects and productivity of tomato plants grown in late summer season. Minufiya J. Agric. Res. , 36 ,(4) : 859-884.

El-Moataaz S., H. Ismael and S. Abo-Rhyem (2019). Assessment of Chemical Composition of Spirulina Platensis and its Effect on Fasting Blood Glucose and Lipid Profile in Diabetic Rats. Journal of High Institute of Public Health;49(3):199-211.

El-Sheekh, M. M. and A. E. F. El-Saied (1999): Effect of seaweed extracts on seed germination, seedling growth and some metabolic processes of faba beans (Vicia faba L.), Phykos, (38) : 55-64.

Ewing, E.E. (1997): Potato in H.C. Wien Ed The physiology of vegetable crops, 295 - 344 CAB International, New York, USA.

Fathy, E-S. L. and S. Farid (1996): The possibility of using vitamin B and yeast to delay senescence and improve growth and yield of common beans (Phaseolus vulgaris L.), J. Agric. Sci. Mansoura Univ. , (4) : 1415-1423.

Fawzy, Z. F., M. M. Abou El-magd, L. Yunsheng, O. Zhu and A. M. Hoda (2012a): Influence of foliar application by EM "Effective Microorganisms", amino acids and yeast on growth, yield and quality of two cultivars of onion plants under newly reclaimed soil. Journal of Agricultural Science, 4 (11): 26-39.

Fawzy, Z. F., Z. S. El-Shal, L. Yunsheng, O. Zhu and O. M. Sawan (2012b): Response of garlic (Allium Sativum L.) plants to foliar spraying of some bio-stimulants under sandy soil condition. Journal of Applied Sciences Research. 8(2): 770776.
Featonby, S. B. C. and J. Van Stadena (1983): The effect of sea weed concentrate on the growth of tomato plants in nematode - infected soil, Scientia Horticulturae, 20 ,(2) : 137-146.

Fornes, F., M. Sánchez-Perales and J. L. Guadiola (2002): Effect of a seaweed extract on the productivity of 'de Nules' Clementine mandarin and navelina orange, Botanica Marina, (45) : 486489.

Gomaa, A. M., S. S. Moawad, I. M. A. Ebadah and H. A. Salim (2005): Application of bio-organic farming and its influence on certain pests infestation, growth and productivity of potato plants. Journal of Applied Sciences Research, 1(2): 205-211.

Hrotko, K., L. Magyar and T. Buban (1996): Effect of benzyladenine application on one-year-old 'Idared' apple trees in the nursery. Hort. Sci., 28: 49-53.

Hussain, W. and L. Khalaf (2007): Effect of foliar spraying with yeast solution on growth and yield of potato plant cv. desiree. html/www.tropentage.de/2007/abstracts/links/kha laf. FPRAXY 90.

Jackson, M. L. (1973): Soil Chemical Analysis. Printice-Hall of India. Privat Limited, New Delhi.

Johanson, D. V. (1940): Plant microtechnique, New York and London McGrow- hill Book Co. Inc.; 27 -154 .

John, M. K. (1970): Colorimeteric determination of phosphoruse in soil plant materials with ascorbic acid. Soil Sci., 109: 214-220.

Khan W., U. P. Rayirath, S. Subramanian, M. N. Jithesh, P. Rayorath, D. M. Hodges, A. T. Critchley, J. S. Craigie, J. Norrie, B. Prithivira (2009): Seaweed extracts as biostimulants of plant growth and development, J. Plant Growth Regul. , $28: 386-399$.

Koshioka M, Harda J, Noma M, Sassa T, Ogiama K, Taylor J S, Rood S B, Legge $R$ L and Pharis R P. (1983). Reversed - phase C18 high performance liquid chromatography of acidic and conjugated gibbberellins. J. Chromatgr; 256:101115.

Letham, D. S. (1969): Cytokinins and their relations to other phytohormones. BioSciences, 19: 309316.

Liestianty D., I. Rodianawati, R. A. Arfah, A. Assa, Patimah, Sundari and Muliadi (2019). Nutritional analysis of spirulina $s p$ to promote as superfood candidate. IOP Conf. Ser.: Mater. Sci. Eng. 509.

Mahmoued, T. R. (2001). Botanical studies on the growth and germination of mahnolia (Magnolia grandiflora L.) plants. M. Sci. Thesis. Fac. of Agric. Moshtohor, Zagazig Univ., Egypt.

Mansowr, F. Y. O. (2012): Effect of chicken manure levels, biofertilizers and some foliar application treatments on garlic production and storability 
(Allium Sativum L.). Ph.D. Thesis, Fac. Agric., Mansoura Univ., Egypt.

Morsi, M. K., B. El-Magoli, N. T. Saleh, E. M. ElHadidy and H. A. Barakat (2008). Study of antioxidants and anticancer activity licorice Glycyrrhiza glabra extracts. Egyptian J. Nutr. and Feeds, 2(33): 177-203.

Murphy, H. J. and M. J. Goven (1959). Factors affecting the specific gravity of the white potato in Maine. Bull. 583, Maine Agric. Exp. Sta. 24 pp.

Murphy, J. and J. P. Riely (1962): A modified single solution method for determination of phosphate in natural. Anal. Chim. Acta., 29:31-36.

Nicander, B. U. S., P. Bjorkman and E. Tillberg (1993). Immyno affinity co-purification of cytokinins and analysis by high-performance liquid chromatography with ultra violet spectrum deterction. planta; (189):312-320.

Osman, Y. M. M. (2015): Effect of some foliar application on yield, quality and storability of garlic. Ph.D. Thesis, Faculty of Agriculture. Ain Shams University., Egypt.

Pervez, M. A., F. Muhammed and E. Mullah (2000): Effect of organic and inorganic manures on physical characteristics of potato (Solanum tuberosum L.). Int. J. Agr. and Bio., 2(1-2): 34-36.

Pregl, F. (1945): Quantitative Organic Micro Analysis. $4^{\text {th }}$ Ed. J. Churchill Ltd. London.

Rama Rao, K. (1991): Effect of seaweed extract on Zyziphus mauratiana Lamk. Journal of Indian Botanical Society 71, 19-21.

Ranganna, S. (1977). Handbook of Analysis and Quality Control for Fruit and Vegetable Product, $2^{\text {nd }}$ ed., Tata McGraw-Hill Comp. Lim.: New Delhi, India.

Sass, J. E. (1951): Botanical micro technique Iowa state college press, Ames, Iowa. 1951; pp.228.
Shady, M. A. (1978): The yeasts, Adv. Cour. For Post Grad. St. In Microbiol, : 146-247. Agric. Bot. Dept., Fac. of Agric., Mansoura Univ.

Shehata, S. M., H. S. Abdel-Azem, H. S. Abou ElYazied and A. M. El-Gizawy (2011): Effect of foliar spraying with amino acids and seaweed extract on growth chemical constitutes, yield and its quality of celeriac plant, European J. of Sci. Res., 58, (2): 257-265.

Sivasankari, S. V., M. Venkatesalu and M. Chandrasekaran (2006): Effect of seaweed extracts on the growth and biochemical constituents of Vigna sinensis, Bio resource Technology, 97: 1745-1751.

Snedecor, G.W. and W. G. Cochran (1980): Statistical Method. $7^{\text {th }}$ Ed., Iowa State Univ. Press, Ames Iowa, USA.

Sotiropoulos, T. E., I. N. Therios, K. N. Dimassi, A. Bosabalidis and G. Kofidis (2002): Nutritional status, growth, $\mathrm{Co}_{2}$ assimilation and leaf anatomical responses in two kiwi fruit species under boron toxicity. J. of Plant Nutrition, 25 (6): 1249-1261.

Taha, N. M., and N. A. S Helal (2019): Effect of Nitrogen Fertilization and Some Foliar Applications on Growth, Yield and Quality of Two Garlic (Allium sativum L.) Cultivars. Current Science International, 8 (1): 212-220.

Wettestein, D. V. (1957): Chlorophyll-Ltale and der submikro skopische from weckses der plastiden Experimental Cell Res.; (12): 427-433.

Winkler, A. J., J. A. Cook, W. M. Kliewer and L. A. Lider (1962): General Viticulture, Univ. Cali. Press,USA.

Xi Q., W. Lai, Y. Cui, H. Wu and T. Zhao (2019). Effect of Yeast Extract on Seedling Growth Promotion and Soil Improvement in Afforestation in a Semiarid Chestnut Soil Area. Forests 2019, 10,76 ; 


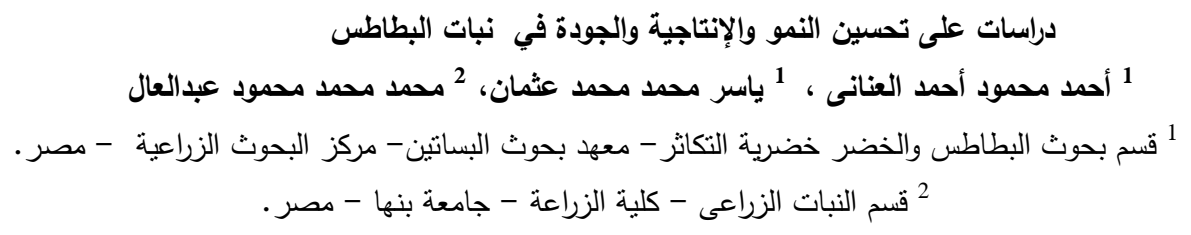

أجريت تجربتان حقليتان بمحطة بحوث الخضـر ، قها ، محافظة القليوبية خلال موسـمى النمو 2017 ، 2018م لدراسـة التأثير المنفرد للرش الورقى بمعاملات البنزيل أدنين بتركيز 25 و 50 جزء فى المليون ومستخلص الطحالب بتركيز 0.3 و 0\% 0.6 ومسـتخلص الخميرة

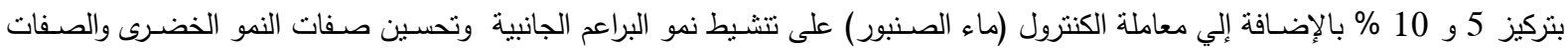
النتريحية والمكونات الكيميائية ومحصول الدرنات وجودته في نباتات البطاطس صنف بيكاسو حيث تم ش النباتات بالمعاملات المستخدمة ثلاث مرات عند 30 و 45 و 60 يوم من الزراعة خلال موسمي الدراسة.

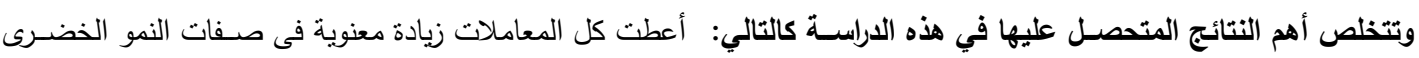

مثل طول وعدد الأفرع الرئيسية والجانبية للنبات وعدد ومسـاحة الأوراق/النبات والأوزان الطازجة والجافة عند عمر 75 يوم من الزراعة وذلك مقارنة

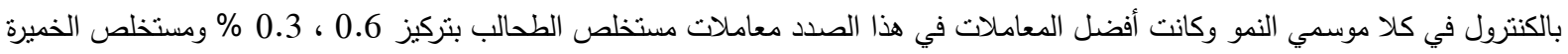
بتركيز 10\% متبوعاً بمعاملة البنزيل أدنين بتركيز 50 جزء فى المليون على الترتيب مقارنة بالكنترول.

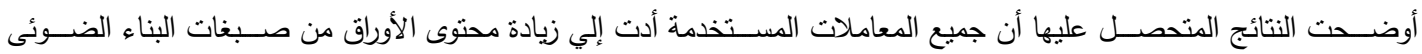

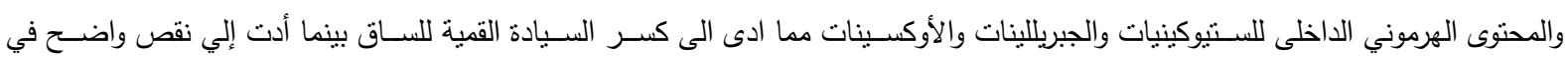

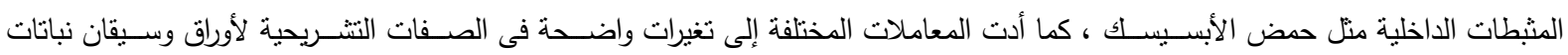
البطاطس وخاصة الجانبية وزيادة الدحصول الناتج من الدرنات/النبات والفدان وتحسين صفات الجودة للارنات وزيادة محتوى الدرنات من المكونات

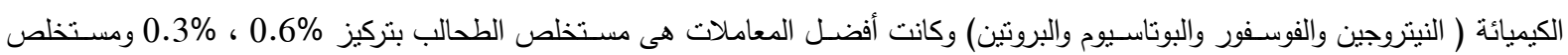
الخميرة بتركيز $10 \%$ ومعاملة البنزيل أدنين بتركيز 50 جزء فى المليون مقارنة بالنباتات الغير معاملة.

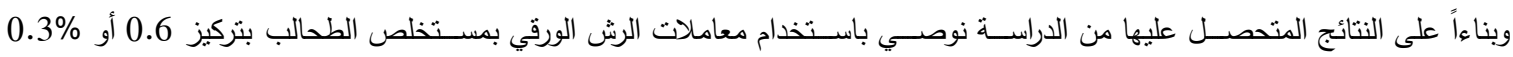
ومستخلص الخميرة بتركيز \% 10 ثلاثة مرات لتحسين صفات النمو و المحصول وجودة الدرنات. 